\title{
Assessment of inter-population genetic diversity and preliminary evaluation of suitable clones of teak (Tectona grandis Linn. F.)
}

\author{
M. K. Behera ${ }^{*}$, N. Bhola ${ }^{2}$, A. K. Parida ${ }^{3}$ and T. R. Pradhan ${ }^{4}$ \\ ${ }^{1}$ NR Management Consultants India Pvt. Ltd. Bhubaneswar, 751003 (Odisha), INDIA \\ ${ }^{2}$ Department of Silviculture \& Agroforesty, College of Forestry, OUAT, Bhubaneswar, 751003 (Odisha), INDIA \\ ${ }^{3}$ Department of Agricultural Statistics, College of Agriculture, OUAT, Bhubaneswar 751003 (Odisha), INDIA \\ ${ }^{4}$ IRRI-OUAT Collaboration Project, OUAT, Bhubaneswar, 751003 (Odisha), INDIA \\ *Corresponding author. E-mail: manojbehera1991@gmail.com
}

Received: June 10, 2015; Revised received: October 5, 2015; Accepted: February 24, 2016

\begin{abstract}
Productivity, uniformity and sustainability are the three important characters of the clonally propagated plants. With the increased use of clonal technology, the scarcity of wood products evidently decreased which has also led to reduced pressure on natural forests and ecosystem. However, the success of clonal technology rests on wise selection and deployment of suitable clones by studying the inter-population genetic diversity. The present study was conducted in a clonal seed orchard (CSO) of teak (Tectona grandis Linn. F.) comprising of 13 different clones to estimate the inter-clonal variation in terms of growth performance and genetic variability at 32 and 33 years of age. Clone ORANP2 exhibited maximum DBH $(26.61 \mathrm{~cm})$, height $(23.69 \mathrm{~m})$, and stem volume $\left(235.40 \mathrm{~m}^{3} \mathrm{ha}\right.$ $\left.{ }^{-1}\right)$ with MAI of $7.133 \mathrm{~m}^{3}$ ha $^{-1}$ year $^{-1}$. The highest CAI of DBH $(1.08 \mathrm{~cm})$ and volume $\left(18.558 \mathrm{~m}^{3} / \mathrm{ha}\right)$ was reported in ORANP5 and ORANR3, respectively. The study found that clone ORANP2 is a superior genotype and thus can be recommended for vegetative multiplication and ex-situ mass planting in reforestation programmes. Both heritability and genetic advance values were low for all the plant traits studied ( $\mathrm{BBH}$, height and stem volume) indicating that these traits are of less use for a tree breeder for furthering the selection and breeding process on teak or other tropical hardwood species across globe.
\end{abstract}

Keywords: Clone, Ex-Situ, Genotype, Heritability, Tectona grandis

\section{INTRODUCTION}

Teak (Tectona grandis Linn. F.) is one of the most valuable and widely planted hardwood species. It occurs naturally in many countries of South-East Asia namely India, Myamnar, the Laos People's Democratic Republic and Thailand. Owing to its desirable wood properties, fine grain, durability, amenability for plantation and increased demand of teak products at both national and international markets the species has been introduced and planted in a number of tropical countries outside its natural range. Moreover, teak timber provides a long term prospect for carbon storage due to a long service life (Bhat, 2003; Keogh, 2003). About one-third (8.9 million hectares) of globally occurring natural teak forests are found in India (International Tropical Timber Organization, 2004), including 1.5 million ha of plantations and 1000 ha of clonal seed orchards (Palanisamy et al., 2009). Further, about 94 per cent of global teak plantation is in tropical Asia, with the major chunk (44 per cent) in India (Pandey and Brown, 2000). The teak tree is indigenous in peninsular India, in the north-eastern drier part of Java and in other islands of Indian Archipelago (Brandis, 1906). In India, it has a discontinuous distribution from its western limit in the western Aravallies at $24^{\circ} 42^{\prime} \mathrm{N}$ Latitude, northern most limit to Jhansi $\left(25^{\circ} 33^{\prime}\right)$ from where it extends to Mahanadi river in the east (Brandis, 1906). The Nilambur man made teak forests first established in 1842 are known to the foresters throughout the world. In Odisha, teak has been introduced or planted in most of the districts across different agro climatic zones. However, Barbara Teak forests which were planted by the British in 1910 find a special place in the research and development of teak in the state. Though teak has managed to secure the top place in timber production all over the country, but the low productivity of teak plantations in India is a major concern for the tree breeders and siliviculturists. In India, low productivity of teak is mostly because of poor seed production in clonal seed orchards as well lack of uniformity in the selection of clonally propagated planting materials (Sreekanth and Balasundaran, 2013; Palanisamy et al., 2009). The average productivity in the state of Kerala is $2.85 \mathrm{~m}^{3} / \mathrm{ha}$ /year over a 53 -year rotation (Palanisamy et al., 2009). This is very low in comparison with other teak growing countries which may be due to limited the use of clonal planting materials during the establishment of both small and large scale teak plantations. Research evidences sug- 
gest that clonal plantations play a vital role in increasing the productivity of forest species by capturing desired genetic characters and maintaining uniformity in growth attributes (Palanisamy et al., 2010). Clonal Seed Orchards (CSO), established through grafts of selected superior trees are considered to be channels of genetically improved seed and starting point for domestication. In spite of several advantages of clonal plantations, genetic improvement of teak has not moved beyond the first generation orchards during the last 50 years (Nicodemus et al., 2009). In Brazil, China and India significant enhancement of productivity has been reported through the application of clonal forestry of eucalyptus and poplar. However, clonal plantation of teak is not operational in India owing to several reasons (Nautiyal et al., 1991).The judicious use of suitable teak clones can bridge up the visible demandsupply gap of teak timber and also enhance the income of the small holder tree growers, thereby contributing towards poverty reduction. In view of the importance of clonal testing in teak for the identification of suitable clones to ensure establishment of genetically uniform and superior plantations, the present study was conducted to evaluate the growth performance and genetic diversity among 13 different teak clones derived from two distinct provenances of Odisha.

\section{MATERIALS AND METHODS}

Study site: The present study was carried out at Silvicultural Research Station, Kosala, Angul of State Forest Department, Odisha, India during January 2013 to June 2014. The experimental site is situated at Kosala, district Angul of Odisha which is located at $21^{\circ} 01^{\prime}$ 17.8"N longitude and 84० 55'19.6"E latitude with an altitude of $440 \mathrm{~m}$ above mean sea level. The experimental field is fairly levelled and well drained. The soil is loamy sand to sandy loam in texture. The soil is slightly acidic in reaction and low in organic carbon, nitrogen and phosphorous. Potassium was low in 0$15 \mathrm{~cm}$ and medium in other depths. The details of soil characteristics are given in table 1 .

Experiment details: The experiment was laid out in Latin Square Design (LSD) with thirteen replications. There were thirteen numbers of clones of Teak as treatments. The clones were planted at a spacing of $4 \mathrm{~m}$ $\times 4 \mathrm{~m}$ in 1981 . The clones were collected from thirteen plus trees of Purunakote and Raigoda provenances of Odisha. In total, there were 169 trees in the experiment.

Tree observations/measurements: Field observations on important growth parameters such as DBH and height of individual trees were recorded by following the standard procedures. Diameter at breast height (DBH) was measured with the help of calliper in two directions following the established guidelines and the average was computed and expressed in $\mathrm{cm}$. The height of trees was measured from ground level to the top of the main shoot with the help of altimeter and
Table 1. Chemical properties of soil at different depths of the experimental area (Mean values are of 13 replicates).

\begin{tabular}{|c|c|c|c|c|}
\hline \multirow{2}{*}{ Particulars } & \multicolumn{4}{|c|}{ Values obtained at different depths of soil } \\
\hline & $0-15 \mathrm{~cm}$ & & & $45-60 \mathrm{~cm}$ \\
\hline $\mathrm{P}^{\mathrm{H}}$ & 6.58 & 6.31 & 6.30 & 6.24 \\
\hline Electrical & & & & \\
\hline $\begin{array}{l}\text { Conductiv- } \\
\text { ity }\left(\mathrm{dSm}^{-1}\right)\end{array}$ & 0.057 & 0.046 & 0.045 & 0.039 \\
\hline $\begin{array}{l}\text { Organic } \\
\text { Carbon }(\%)\end{array}$ & 0.324 & 0.404 & 0.444 & 0.424 \\
\hline $\begin{array}{l}\text { Available N } \\
\left(\mathrm{Kg} \mathrm{ha}^{-1}\right)\end{array}$ & 162.5 & 162.5 & 137.5 & 112.5 \\
\hline $\begin{array}{l}\text { Available } \\
\mathrm{P}_{2} 0_{5}\left(\mathrm{Kg} \mathrm{ha}^{-1}\right)\end{array}$ & 10.7 & 9.0 & 7.9 & 6.2 \\
\hline $\begin{array}{l}\text { Available } \\
\mathrm{K}_{2} \mathrm{O}\left(\mathrm{Kg} \mathrm{ha}^{-1}\right)\end{array}$ & 95.4 & 157.2 & 205.6 & 223.1 \\
\hline
\end{tabular}

expressed in meter. Then, the volume of stem per tree was calculated by the formula given by Forest Survey of India (FSI, 1996) for Odisha i.e.

$\operatorname{VUB}\left(\mathrm{m}^{3}\right)=-0.0645+0.2322 \mathrm{D}^{2} \mathrm{H}$

Where, VUB $=$ Volume under bark

$\mathrm{D}=\mathrm{DBH}$ over bark

$\mathrm{H}=$ Height of the tree

The volume of stem per hectare was calculated by multiplying the average volume of stem per tree with plant population per ha. It was expressed in $\mathrm{m}^{3} / \mathrm{ha}$.

To know the increment potential of different clones, attempts were made to record the readings of the above mentioned plant traits in two consecutive years. The $\mathrm{CAI}$ in $\mathrm{DBH}$, height and volume was determined from the differences of the parameters recorded in January 2013 and January, 2014 and expressed in $\mathrm{cm}$, $\mathrm{m}$ and $\mathrm{m}^{3} / \mathrm{ha}$, respectively. The MAI of stem volume per hectare was calculated by dividing the total volume per hectare by the age of trees. It was expressed in $\mathrm{m}^{3} / \mathrm{ha} /$ year. The data on these observations were analyzed as per the procedure described for LSD and DMRT (Duncan Multiple Range Test).

\section{Genetic studies}

The phenotypic coefficient of variation (PCV) was calculated by using the formula given by Singh and Chaudhary (1985).

$$
\mathrm{PCV}=\left(\sigma_{p} / \bar{X}\right) \times 100
$$

Where, $\sigma_{\mathrm{p}}=$ phenotypic standard deviation and $\bar{X}=$ grand mean of the trait.

The genotypic coefficient of variation (GCV) was calculated by using the formula given by Singh and Chaudhary (1985).

$\mathrm{GCV}=\left(\sigma_{\mathrm{g}} / \overline{\mathrm{X}}\right) \times 100$

Where, $\sigma_{\mathrm{g}}=$ genotypic standard deviation.

The heritability in the broad sense $\left(\mathrm{H}^{2}\right)$ was estimated by using the formula prescribed by Allard (1999).

Heritability $(\%)=\left(\sigma^{2} g / \sigma^{2} p\right) \times 100$

Where, $\sigma^{2} \mathrm{~g}=$ genotypic variance, $\sigma^{2} \mathrm{p}=$ phenotypic 
Table 2. Growth and volume production in different clones of teak (Mean values are of 13 replicates).

\begin{tabular}{|c|c|c|c|c|c|c|}
\hline \multirow{2}{*}{ Treatments/Clones } & \multicolumn{2}{|l|}{ DBH (cm) } & \multicolumn{2}{|c|}{ Total height (m) } & \multicolumn{2}{|c|}{ Stem volume $\left(\mathrm{m}^{3} / \mathrm{ha}\right)$} \\
\hline & 32 year old & 33 year old & 32 year old & 33 year old & 32 year old & 33 year old \\
\hline ORANP1 & $18.15^{\mathrm{c}}$ & $18.52^{\mathrm{c}}$ & $19.44^{\circ}$ & $19.48^{\circ}$ & $62.792^{0}$ & $68.862^{\circ}$ \\
\hline ORANP2 & $25.76^{\mathrm{a}}$ & $26.61^{\mathrm{a}}$ & $23.67^{\mathrm{a}}$ & $23.69^{\mathrm{a}}$ & $219.335^{\mathrm{a}}$ & $235.404^{\mathrm{a}}$ \\
\hline ORANP3 & $22.29^{\mathrm{abc}}$ & $23.26^{\mathrm{abc}}$ & $22.64^{\mathrm{a}}$ & $22.67^{\mathrm{ab}}$ & $145.397^{\mathrm{ab}}$ & $162.430^{\mathrm{ab}}$ \\
\hline ORANP4 & $19.75^{\mathrm{bc}}$ & $20.42^{\mathrm{bc}}$ & $21.24^{\mathrm{ab}}$ & $21.28^{\mathrm{ab}}$ & $105.102^{\mathrm{b}}$ & $116.096^{\mathrm{b}}$ \\
\hline ORANP5 & $20.30^{\mathrm{bc}}$ & $20.98^{\mathrm{bc}}$ & $21.72^{\mathrm{ab}}$ & $21.76^{\mathrm{ab}}$ & $101.214^{\mathrm{b}}$ & $112.029^{\mathrm{b}}$ \\
\hline ORANP6 & $21.12^{\mathrm{abc}}$ & $21.64^{\mathrm{abc}}$ & $21.87^{\mathrm{ab}}$ & $21.91^{\mathrm{ab}}$ & $127.016^{\mathrm{ab}}$ & $137.352^{\mathrm{ab}}$ \\
\hline ORANP7 & $21.88^{\mathrm{abc}}$ & $22.88^{\mathrm{abc}}$ & $22.59^{\mathrm{ab}}$ & $22.63^{\mathrm{ab}}$ & $131.598^{\mathrm{ab}}$ & $149.358^{\mathrm{ab}}$ \\
\hline ORANR1 & $20.91^{\mathrm{bc}}$ & $21.44^{\mathrm{bc}}$ & $20.96^{\mathrm{ab}}$ & $20.99^{\mathrm{ab}}$ & $119.782^{\mathrm{b}}$ & $128.588^{\mathrm{b}}$ \\
\hline ORANR2 & $19.37^{\mathrm{bc}}$ & $20.24^{\mathrm{bc}}$ & $20.57^{\mathrm{ab}}$ & $20.62^{\mathrm{ab}}$ & $87.370^{\mathrm{b}}$ & $100.153^{b}$ \\
\hline ORANR3 & $23.40^{\mathrm{ab}}$ & $24.38^{\mathrm{ab}}$ & $23.16^{\mathrm{a}}$ & $23.19^{\mathrm{a}}$ & $153.399^{\mathrm{ab}}$ & $171.683^{\mathrm{ab}}$ \\
\hline ORANR4 & $21.40^{\mathrm{abc}}$ & $22.16^{\mathrm{abc}}$ & $22.42^{\mathrm{ab}}$ & $22.47^{\mathrm{ab}}$ & $119.775^{\mathrm{b}}$ & $132.855^{\mathrm{ab}}$ \\
\hline ORANR5 & $21.79^{\mathrm{abc}}$ & $22.87^{\mathrm{abc}}$ & $21.92^{\mathrm{ab}}$ & $21.92^{\mathrm{ab}}$ & $122.972^{b}$ & $140.957^{\mathrm{ab}}$ \\
\hline ORANR6 & $22.95^{\mathrm{abc}}$ & $23.91^{\mathrm{ab}}$ & $23.30^{\mathrm{a}}$ & $23.33^{\mathrm{a}}$ & $148.085^{\mathrm{ab}}$ & $163.686^{\mathrm{ab}}$ \\
\hline $\mathrm{SE}_{(\mathrm{m})}$ & 1.46 & 1.54 & 1.02 & 1.01 & 0.046 & 0.0506 \\
\hline
\end{tabular}

variance

$\sigma^{2} \mathrm{~g}=(\mathrm{MSG}-\mathrm{MSE} / \mathrm{r})$

$\sigma^{2} \mathrm{p}=(\mathrm{MSG} / \mathrm{r})$

Where, MSG, MSE and $r$ are the mean squares of genotypes, mean squares of error and number of replication, respectively.

Genetic advance percentage was calculated by using the formula proposed by Shukla et al. (2006).

GA $(\%)=(G A / \bar{X}) \times 100$

Where, $\mathrm{GA}=$ genetic advance $\left(\mathrm{i} \sigma_{\mathrm{p}} \mathrm{H}^{2}\right)$

and $=\bar{x}$ grand mean of the trait.

Where, $i$ is the standardized selection differ- ential, a constant (2.06), $\sigma_{\mathrm{p}}$ is the phenotypic standard deviation and $\mathrm{H}^{2}$ is the heritability.

\section{RESULTS AND DISCUSSION}

In Odisha, the diameter at breast height of different teak clones varied from $18.15 \mathrm{~cm}$ to $25.76 \mathrm{~cm}$ at the age of 32 years (Table 2). Among the clones studied, maximum DBH of $25.76 \mathrm{~cm}$ was demonstrated by ORANP2 whereas the lowest value was reported in ORANP1. The values under ORANP2, ORANP3, ORANP6, ORANP7, ORANR3, ORANR5 and ORANR6 were found statistically similar. Similar trend was noticed in diameter growth at the age of 33 years. Similarly at 33 years old, the DBH ranged from $18.52 \mathrm{~cm}$ to $26.61 \mathrm{~cm}$. In Kerala, India, Palanisamy et al. (2009) has reported girth at breast height (gbh) among some selected superior clones in the range of $151-220 \mathrm{~cm}(48-70 \mathrm{~cm}$ $\mathrm{DBH})$ at the age of 51-64 years. Reddy and Madiwalar, (2014) observed $18.82 \mathrm{~cm}$ mean diameter growth in a 20 year old plantation in different agro climatic zones of Karnataka. Rao et al. (2001) also reported that dbh growth of 26 year old teak provenances in Andhra Pradesh ranged from 42.80 to 69.78 $\mathrm{cm}$. The comparison of growth of teak clones with the empirical study findings indicates a similar growth trend though the location of the sites differs. The relatively higher DBH growth in ORANP2 may be ascribed due to better genetic character of the clone and the poor performance of ORANP1 may be to poor genetic makeup of the clone. Most of the clones showed similar growth which indicates that there is no significant difference in genetic makeup of the clones with regard to lateral growth of the stem at this age. As all the clones are derived from two distinct provenances of the same district, environmental variation is very less. Therefore, whatever phenotypic variations observed are mostly the impact of genotypes (Genotype $\times$ Environment $=$ Phenotype). Provenance variation and tree to tree variation accounts for as much as $90 \%$ of the within species variation, leading to the fastest gains in most tree improvement programmes being obtained by selection from the best seed source within the appropriate species (Zobel and Talbert, 1984). Here, the provenance variation is also very less which is mainly due to the location of both the provenances within a small geographical or territorial boundary (district). Similar observations were noticed in case of height growth which varied from $19.44 \mathrm{~m}$ to $23.67 \mathrm{~m}$ and was $19.48 \mathrm{~m}$ to $23.69 \mathrm{~m}$ at 32 and 33 years of age, respectively (Table 2). ORANP2 exhibited the maximum height growth, while the minimum height was observed in ORANP1. The height growth under ORANP2, ORANP3, ORANP4, ORANP5, ORANP6, ORANP7, ORANR1, ORANR7, ORANR3, ORANR4 and ORANR6 were statistically similar. Rao et al. (2001) also reported that the height growth in a 26 year old teak provenances in Andhra Pradesh ranged from 14.33 to $22.33 \mathrm{~m}$. This implies that the clones studied in the present experiment are exhibiting sound growth trend with regards to tree height. The closeness in height growth among different clones may be attributed to less variation in their genetic characters.

The data pertaining to stem volume per hectare manifested significant difference among different clones of teak at the age of 32 years as well as 33 years of the stand (Table 2). At 32 year old, ORANP2 evinced the highest stem volume production of $219.335 \mathrm{~m}^{3} / \mathrm{ha}$ whereas ORANP1 produced least volume of stem wood $\left(62.792 \mathrm{~m}^{3} /\right.$ ha. $)$. The volume of stem wood produced by ORANP2, ORANP3, ORANP6, ORANP7 and 
ORANR3 were at par with each other. At 33 year old, ORANP2 registered maximum stem volume of $235.404 \mathrm{~m}^{3} /$ ha which was significantly higher over the volume of wood produced by ORANP1, ORANP4, ORANP5, ORANR1 and ORANR2. ORANP1 produced the minimum quantity of stem wood $\left(68.862 \mathrm{~m}^{3} / \mathrm{ha}\right)$. The performance with regard to stem volume under ORANP2, ORANP3, ORANP6, ORANP7, ORANR3, ORANR4 and ORANR5 wre statistically alike. The order of stem wood production was ORANP2 > ORANR3 > ORANR6 > ORANP3 > ORANP7 > ORANP6 > ORANR5 > ORANR1 > ORANR4 > ORANP4 > ORANP5 > ORANR2 > ORANP1. The higher accumulation of stem volume in ORANP2 may be ascribed for the presence of better genetic characters over others which govern the apical and lateral growth of stem. The lowest volume production by ORANP1 may be due to the poor genetic characters in terms of diameter and height growth which has been reflected in table 3 . Reddy and Madiwalar, (2014) reported that at this stage of growth, the CAI of diameter at breast height differ appreciably among various clones of Teak studied. ORANP5 registered maximum increment of $1.08 \mathrm{~cm}$ followed by ORANP7, ORANR2, ORANP6 and ORANP3. The DBH increment during this period was lowest under ORANP1 $(0.36 \mathrm{~cm})$. The CAI of DBH under ORANP1, ORANP2, ORANP4, ORANP5, ORANP6, ORANR1, ORANR2 and ORANR4 were statistically at par with each other. This indicates that ORANR5 possesses more secondary meristem enhancement potential at this age than others and ORANR1 possesses the lowest secondary meristem enhancement at this age.

The difference in CAI of height during 32 and 33 years was observed among some clones (Table 3 ). The highest value of $0.05 \mathrm{~m}$ was recorded under ORANP2, ORANR4 and ORANP5 and the lowest value $(0.01 \mathrm{~m})$ was recorded under ORANP5. The values under ORANP1, ORANP2, ORANP3, ORANP4, ORANP6, ORANP7, ORANR1, ORANR5 and ORANR6 were found to be in the same statistical group. This implies that variation among these clones with regard to the CAI values is negligible. The higher increment in height of ORANR2 and ORANP5 may be attributed to relatively more activeness of apical meristem at this age in comparison to other clones. The lowest increment in height of ORANR5 may be due to slow down of apical meristem at this age in comparison to others. In regard to CAI of stem volume, clone ORANR3 registered relatively higher value of $\left(18.558 \mathrm{~m}^{3} / \mathrm{ha}\right)$, closely followed by ORANR5, ORANP7, ORANP3 and ORANP2. The lowest value $\left(6.362 \mathrm{~m}^{3} / \mathrm{ha}\right)$ was found under ORANP1. The CAI of stem volume did not vary significantly which may be due to the fact that the genetic characters of the clones are similar with regard to expansion of primary meristem and secondary meristem at this age. The MAI of stem volume at 32 and 33 years of age varied from $1.962-6.854 \mathrm{~m}^{3} /$ ha/year and $2.087-7.133 \mathrm{~m}^{3} /$ ha/year, respectively. ORANP2 witnessed the maximum value while ORANP1 detected the minimum value. ORANP2 accumulated highest MAI whereas ORANP1 achieved the lowest. Chundamanil (1998) reported a mean annual increment (MAI) of $2.854 \mathrm{~m}^{3} \mathrm{ha}^{-1} \mathrm{year}^{-1}$ in a 53 years rotation of teak in Kerala, Similarly, Rao et al. (2002) has observed a MAI of more than $8 \mathrm{~m}^{3} /$ ha/year in the best performing clones in Andhra Pradesh, India. The performance of ORANP2, ORANP3, ORANP6, ORANP7, ORANR3 and ORANR6 were statistically similar at the age of 32 to 33 years which may be because of closeness in genetical characters governing expansion of primary and secondary meristem at this age.

The phenotypic coefficient of variation (PCV) revealed a little variation among different traits of teak (Fig. 1) which ranged from $3.04-26.31 \%$. Maximum variation was observed in stem volume production $(26.31 \%)$. The order of variation was found to be stem volume > DBH > clear bole height $>$ total height. Similar trend was noticed for genotypic coefficient of variation

Table 3. Annual increments in growth in different clones of teak (Mean values are 13 replicates).

\begin{tabular}{llllll}
\hline $\begin{array}{l}\text { Treatments/ } \\
\text { Clones }\end{array}$ & $\begin{array}{l}\mathbf{C A I}_{\mathbf{3 2 - 3 3}} \text { of DBH } \\
(\mathbf{c m})\end{array}$ & $\begin{array}{l}\mathbf{C A I}_{\mathbf{3 2 - 3 3}} \text { of height } \\
(\mathbf{m})\end{array}$ & $\begin{array}{l}\mathbf{C A I}_{\mathbf{3 2}-33} \text { of stem } \\
\text { volume }\left(\mathbf{m}^{\mathbf{3}} / \mathbf{h a}\right)\end{array}$ & $\begin{array}{l}\text { MAI of stem volume }\left(\mathbf{m}^{\mathbf{3}} / \mathbf{h a} / \mathbf{y e a r}\right) \\
\text { 32 year old }^{\mathrm{33year} \text { old }}\end{array}$ \\
\hline ORANP1 & $0.36^{\mathrm{b}}$ & $0.04^{\mathrm{ab}}$ & $6.362^{\mathrm{a}}$ & $1.962^{\mathrm{b}}$ & $2.087^{\mathrm{b}}$ \\
ORANP2 & $0.85^{\mathrm{ab}}$ & $0.02^{\mathrm{ab}}$ & $16.029^{\mathrm{a}}$ & $6.854^{\mathrm{a}}$ & $7.133^{\mathrm{a}}$ \\
ORANP3 & $0.97^{\mathrm{a}}$ & $0.04^{\mathrm{ab}}$ & $16.805^{\mathrm{a}}$ & $4.544^{\mathrm{ab}}$ & $4.922^{\mathrm{ab}}$ \\
ORANP4 & $0.67^{\mathrm{ab}}$ & $0.03^{\mathrm{ab}}$ & $11.096^{\mathrm{a}}$ & $3.284^{\mathrm{b}}$ & $3.518^{\mathrm{b}}$ \\
ORANP5 & $0.68^{\mathrm{ab}}$ & $0.05^{\mathrm{a}}$ & $10.77^{\mathrm{a}}$ & $3.163^{\mathrm{b}}$ & $3.395^{\mathrm{b}}$ \\
ORANP6 & $0.52^{\mathrm{ab}}$ & $0.04^{\mathrm{ab}}$ & $10.476^{\mathrm{a}}$ & $3.969^{\mathrm{ab}}$ & $4.162^{\mathrm{ab}}$ \\
ORANP7 & $1.00^{\mathrm{a}}$ & $0.04^{\mathrm{ab}}$ & $17.482^{\mathrm{a}}$ & $4.112^{\mathrm{ab}}$ & $4.526^{\mathrm{ab}}$ \\
ORANR1 & $0.53^{\mathrm{ab}}$ & $0.03^{\mathrm{ab}}$ & $8.587^{\mathrm{a}}$ & $3.743^{\mathrm{b}}$ & $3.897^{\mathrm{b}}$ \\
ORANR2 & $0.87^{\mathrm{ab}}$ & $0.05^{\mathrm{a}}$ & $12.652^{\mathrm{a}}$ & $2.730^{\mathrm{b}}$ & $3.035^{\mathrm{b}}$ \\
ORANR3 & $0.98^{\mathrm{a}}$ & $0.03^{\mathrm{ab}}$ & $18.558^{\mathrm{a}}$ & $4.794^{\mathrm{ab}}$ & $5.203^{\mathrm{ab}}$ \\
ORANR4 & $0.76^{\mathrm{ab}}$ & $0.05^{\mathrm{a}}$ & $12.854^{\mathrm{a}}$ & $3.743^{\mathrm{b}}$ & $4.026^{\mathrm{ab}}$ \\
ORANR5 & $1.08^{\mathrm{a}}$ & $0.01^{\mathrm{b}}$ & $17.832^{\mathrm{a}}$ & $3.843^{\mathrm{b}}$ & $4.271^{\mathrm{ab}}$ \\
ORANR6 & $0.96^{\mathrm{a}}$ & $0.03^{\mathrm{ab}}$ & $15.560^{\mathrm{a}}$ & $4.628^{\mathrm{ab}}$ & $4.960^{\mathrm{ab}}$ \\
SE (m) & 0.18 & 0.014 & 0.006 & 0.001 & 0.001 \\
\hline
\end{tabular}

\footnotetext{
*Means with the same letter are not significantly different.
} 


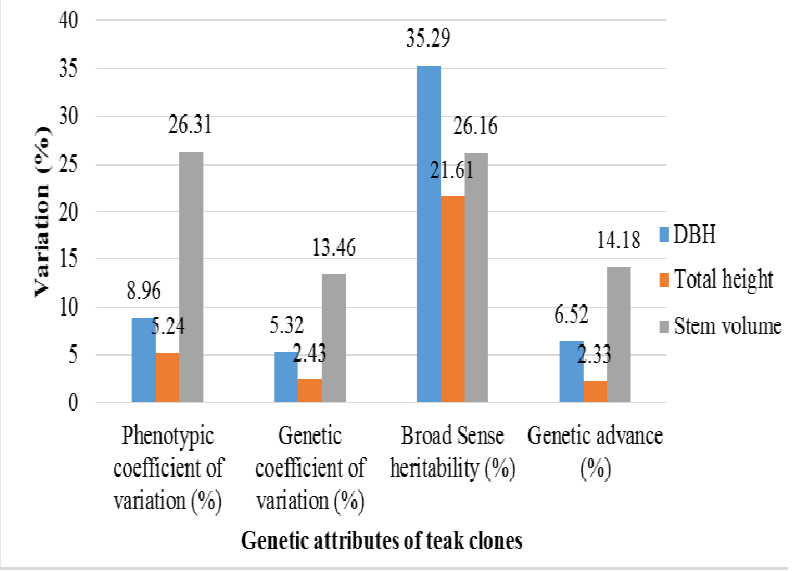

Fig. 1. Genetic attributes of important plant traits studied.

(GCV). The less difference between PCV and GCV of the concerned trait indicates that the environmental variations are either negligible or absent. The interpopulation genetic variations observed in Teak are mainly ascribed to factors such as reduced gene flow, variation in natural selection intensity and genetic drift. As most of the tropical hardwoods are insect pollinated, the flow of genes is confined to a small geographical area which reduces the genetic and environmental variation and also make the selection process restrictive.

Heritability is the genetic portion of the differences among trees, with the remaining portion is caused by the environment. All the quantitative traits i.e. $\mathrm{DBH}$, total height and stem volume exhibited low broad sense heritability in the teak clones studied. Lower heritability indicated that the particular trait is of little importance for a tree breeder to do further selection and improvement programme. The genetic advance of different traits varied from 2.33 to 14.18 percent which may be categorized as low level of genetic advance. Lower values of expected genetic advance for various plant traits revealed predominant role of non-additive gene action. The non-additive gene action consists of two parts i.e. dominance and epistatic. Dominance tells us that a given allele is masking the partner allele, whereas; epistatic indicates the nature of interactions among loci. Here, both dominance and epistatic has major roles in the growth of the genotypes. Additional genetic gains may be obtained by capturing the nonadditive genetic variation through vegetative propagation, which is considered to be one important advantage of clonal forestry.

\section{Conclusion}

While selecting the clones for vegetative propagation, it is quite imperative to ensure that the genotypes chosen are superior for the desired traits and also selected from a genetically diverse population. Considering the importance of identification and deployment of suitable clones for increased wood production, this par- ticular study recommend the vegetative multiplication of tested clone ORANP2 which manifested highest stem volume of $235.404 \mathrm{~m}^{3} /$ ha and MAI of $7.133 \mathrm{~m}^{3} / \mathrm{ha}$ at the age of 33 year for ex-situ mass planting in many current reforestation programmes. Further, the genetic analysis also leads us to clear understanding of different quantitative traits and their extent of contributions to wood yield. All the characters studied reflect lower genetic heritability (21.61 to $35.29 \%$ ) coupled with low genetic advance (6.52 to $14.18 \%$ ) indicating that these plant traits shall not be considered for further selection and improvement programme on Teak and other tropical hard wood species. The genetic analysis would also help us in understanding, conserving and harnessing the genetic biodiversity of important tree species across the world.

\section{ACKNOWLEDGEMENTS}

The authors are thankful to the State Forest Department, Odisha and OUAT for providing all necessary supports for accomplishing the study.

\section{REFERENCES}

Allard, R.W. (1999). Principles of plant breeding. 2nd edn. New York, John Wiley \& Sons. 254pp

Bhat K. (2003). Quality concerns of sustainable teakwood chain. Paper presented at the ITTO/Kerala Forest Research Institute International Conference on Quality Timber Products of Teak from Sustainable Forest Management, 2-5 December 2003, Peechi, India.

Brandis. Dietrich. (1906): "Indian Trees". London. Archibald Constable and Co. Ltd. 767 pp

Chundamnil, Mammen. (1998). Teak Plantations in Nilambur- an economic review. KFRI Research Report, (144): 1-48.

FSI (1996). Volume equations for forests of India, Nepal and Bhutan. Forest Survey of India, Ministry of Environment and Forests, Govt. of India. pp. 249.

International Tropical Timber Organization (ITTO). (2004). The Prospects for plantations of Teak. Tropical Forest Update, 14(1): 8-14.

Keogh, R. (2003). The importance of quality teak in plantations. Paper presented at the ITTO/Kerala Forest Research Institute International Conference on Quality Timber Products of Teak from Sustainable Forest Management, 2-5 December 2003, Peechi, India

Nautiyal, S.; Singh, Uma. And Gurumurti, K. (1991). Rooting response of branch cuttings of Teak as influenced $b$ season and growth hormones. Indian Forester, 117(4): 249-255.

Nicodemus, A.; Vergehese, M.; Nagarajan, B. and Lindgren, D, (2009). Annual Fertility Variation in Clonal Seed Orchards of Teak (Tectona grandis L. F.) and its impact on Seed Crop. Silvae Genetica, 58:1-2.

Palanisamy, K.; Gireesan, K.; Nagarajan, V. and Hegde, M. (2009). Selection and clonal multiplication of superior clones of Teak and preliminary evaluation of clones. Journal of Tropical Forest Science, 21(2): 168-174.

Palanisamy, K.; Krishnamoorthy, M.; Gireesan K. and Rajasekar, S. (2010). Recent trends in Teak improvement in India. Teaknet Bulletin, 3(3): 2-8.

Pandey, D. and Brown, C. (2000). Teak: A global overview. 
Unasylva, 51(201): 3-13.

Rao, P.S.; Venkaiah, K.; Murali, V.; Murti, S.S.N. and Sattar, S.A. (2001). Evaluation of International Teak Provenance Trial plot in North East Andhra Pradesh. Indian-Forester, 127(4): 415-422.

Rao, P.S.; Murali, V,; Venkaiah K. and Murti, S.S.N. (2002). Performance of teak (Tectona grandis Linn.F.) clones of Andhra Pradesh. Indian Forester, 128(12): 1288-1294.

Reddy, M.C. and Madiwalar, S.L. (2014). Productivity Assessment and Economic Analysis of Teak Plantations in Different Agroclimatic zones of Karnataka. Indian Forester, 140 (3): 287-290.

Shukla S., A. Bhargava, A. Chatterjee, J. Sirivastava, N.
SIngh, S.P. Singh. (2006). Mineral profile and variability in vegetable amaranth (Amaranthus tricolor). $\mathrm{Pl}$. Foods Hum. Nut., 61, 23-28.

Singh, R.K. and Choudhary, B.D. (1985). Biometrical Methods in Quantitative Genetic Analysis. Kalyani Publishers, New Delhi, p.318.

Sreekanth, P.M. and Balasundaran, M. (2013), Clonal Seed Orchard of Teak (Tectona grandis L.f.): Genetic Diversity Measures Primary Basis for Future Environmental Uncertainty, Tree Genetics and Molecular Breeding 3 (2): 4-11

Zobel B \& Talbert J. (1984). Applied Forest Tree Improvement. John Wiley \& Sons Inc, New York. 